\title{
Oil Spills, Gas Flaring and Adverse Pregnancy Outcomes: A Systematic Review
}

\author{
Onome B. Oghenetega1 ${ }^{*}$, Godson R. E. E. Ana², Michael A. Okunlola ${ }^{3}$, Oladosu A. Ojengbede ${ }^{3}$ \\ ${ }^{1}$ Pan African University Life and Earth Sciences Institute, Department of Obstetrics and Gynecology, College of Medicine, \\ University of Ibadan, Ibadan, Nigeria \\ ${ }^{2}$ Department of Environmental Health, Faculty of Public Health, University of Ibadan, Ibadan, Nigeria \\ ${ }^{3}$ Department of Obstetrics and Gynecology, College of Medicine, University College Hospital, University of Ibadan, Ibadan, Nigeria \\ Email: ^tegabonome@gmail.com
}

How to cite this paper: Oghenetega, O.B., Ana, G.R.E.E., Okunlola, M.A. and Ojengbede, O.A. (2020) Oil Spills, Gas Flaring and Adverse Pregnancy Outcomes: A Systematic Review. Open Journal of Obstetrics and Gynecology, 10, 187-199.

https://doi.org/10.4236/ojog.2020.1010016

Received: October 17, 2019

Accepted: January 13, 2020

Published: January 16, 2020

Copyright $\odot 2020$ by author(s) and Scientific Research Publishing Inc. This work is licensed under the Creative Commons Attribution International License (CC BY 4.0).

http://creativecommons.org/licenses/by/4.0/

\begin{abstract}
Oil spills and gas flaring are major environmental problems and pose major source of adverse health outcomes to communities hosting oil wells and natural gas. As oil is spilt and gas is flared; air, soil and water in affected communities are polluted. Due to this, members of these communities are exposed to higher health risks. One vulnerable group that is usually affected in this regard is pregnant women. This systematic review identified and reviewed past studies on oil pollution and different types of pregnancy outcomes within a twenty-year gap, which is between 1999 and 2019. The review also discussed the exposure pathways of oil pollution. From a literature search on scientific databases conducted in August 2019 for articles relating to the objectives of the review, data were extracted from articles which met the inclusion criteria and contents were systematically analyzed based on types of pregnancy outcomes. This review showed that oil spill and gas flaring may put pregnant women at high risk of hypertensive disorders of pregnancy, gestational diabetes mellitus, maternal depression, miscarriages via three pathways. This review may be of some use in making policy in this area.
\end{abstract}

\section{Keywords}

Oil Spills, Gas Flaring, Pregnancy Outcomes

\section{Introduction}

Oil spills and gas flaring are common occurrences in crude oil-producing communities. Globally, almost all the communities hosting an estimated 70,000 oil fields across 100 countries have experienced oil spills and gas flaring at one point or the other [1] [2] [3] [4] [5]. Apart from the economic wastage accruing from 
oil spills and gas flaring, it is a major source of health problems to communities hosting oil wells and natural gas. In Nigeria, major oil exploration takes place in the Niger Delta region of the country, thus the health and environmental hazards resulting from oil pollution in this region cannot be overemphasized.

Environmental degradation from crude oil exploration and extraction activities have posed significant health risk to residents in oil-rich regions. Majority of these residents are susceptible to health problems; however some population sub-groups, like pregnant women, are more vulnerable. The developmental phases of a fetus during pregnancy are highly sensitive. Any form of unhealthy exposure to environmental pollutants can lead to increased risk of adverse fetal and maternal outcomes. Environmental pollutants that are released when oil is spilt and gas flared have the potential to affect both the mother and growing fetus through maternal exposure before conception, during pregnancy and after delivery [6].

This is in consonance with several studies that have reported that maternal exposure to environmental toxicants poses a major risk to the health of the women as well as having negative impact on fetal health and development [7] [8] [9]. There is a body of evidence relating maternal exposure to oil pollutants with increased risk of miscarriage, intrauterine growth restriction, low birth weight, birth defects, gestational diabetes mellitus, maternal depression, motor and cognitive delays in children [7] [10] [11] [12]. Thus, this article reviews the adverse outcomes of pregnancy associated with exposure to oil spill and gas flaring and its possible exposure pathways.

\section{Method}

\subsection{Scope of Review}

Pregnancy outcomes originating from exposure to oil pollution varies. This review focused on literature relating to adverse pregnancy outcomes such as hypertensive disorders of pregnancy, gestational diabetes mellitus, maternal depression, miscarriage and stillbirth, low birthweight, birth defects and neonatal mortality as a result of exposure to oil spill and gas flaring. We also reviewed the literature on exposure pathways; such as through air, water and soil. Studies using case-control, vital records, health-based organizations' reports, cross-sectional studies and longitudinal cohort studies were included.

\subsection{Identification of Relevant Studies}

A literature search on studies relating to the topic was conducted in the online databases including Medline, Google scholar and African Journal Online (AJOL) between August and September 2019. Manual searches were also done in the main Library of University of Ibadan, Nigeria (Kenneth Dike Library), for peer-reviewed journals on the topic. There was no date for termination of search; however, the last search was conducted on September 5, 2019. A combination of keywords including "oil pollution OR oil spill OR gas flaring", "preg- 
nancy outcomes OR maternal outcomes OR neonatal outcomes", "oil pollution OR oil spill OR gas flaring AND Pregnancy”, "oil pollution OR oil spill OR gas flaring AND adverse pregnancy outcomes OR adverse maternal outcomes OR adverse neonatal outcomes", "oil pollution OR oil spill OR gas flaring AND exposure pathways" were used on each search.

\subsection{Study Selection Criteria}

Our interest lies in identifying literature relating to adverse pregnancy outcomes with regards to oil pollution exposure. In addition, our literature search focused on studies whose contents included oil pollution exposure pathways such as air, water and soil. Studies that do not fall within the scope of the review were excluded. Abstracts for the literature were carefully read to determine whether they can be included or not in the study. Afterwards, the full-text version of such studies was downloaded for further analysis. Information relating to the year of study, study design, country of research, study population and sample size as well as research findings were extracted from each paper. Table 1 shows the studies that fit into the inclusion criteria and was therefore used in this review.

\section{Results}

\subsection{Study Selection and Characteristics}

The initial search produced 417 articles. After a careful review of the abstracts, 312 papers were excluded because they did not meet the inclusion criteria while the remaining 105 papers fitted the category of literature needed. The full text of the 105 journals were downloaded and read. These papers were then further screened and 81 were excluded (36 were duplicate studies; 21 had study population of girls and women who were not within the reproductive age while 25 were studies in which results on health outcomes of oil pollution for men were taken together with results on the effects of oil pollution on pregnant women and other categories of population). Twenty-three (23) papers were eventually used for this review as shown in Figure 1.

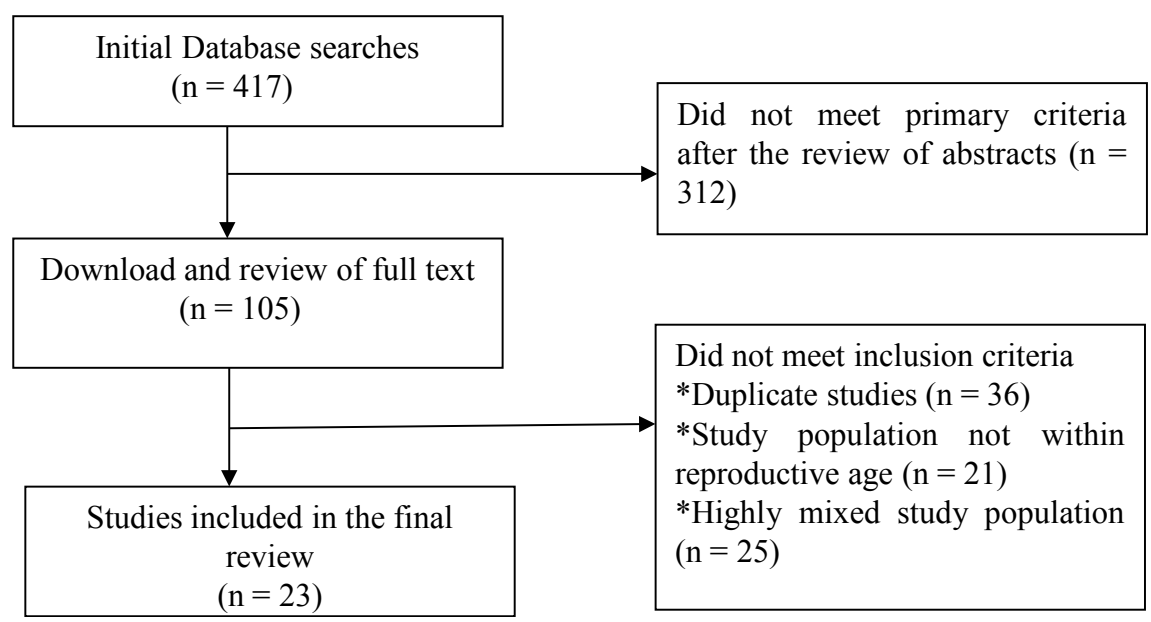

Figure 1. Flow chart of study selection. 
Table 1. List of journal papers reviewed on pregnancy outcomes and exposure pathways of oil pollution.

\begin{tabular}{|c|c|c|c|c|c|c|}
\hline $\mathrm{S} / \mathrm{N}$ & Author(s) names & Year & Country & Study design & $\begin{array}{l}\text { Study population and } \\
\text { sample (s) }\end{array}$ & Findings \\
\hline 1 & Dugandzic, et al. & 2006 & Canada & $\begin{array}{l}\text { Retrospective cohort } \\
\text { study }\end{array}$ & $\begin{array}{l}\text { Live singleton births ( } \geq 37 \\
\text { weeks of gestation) between } \\
\text { January } 1,1988 \text { and } \\
\text { December } 31,2000 .\end{array}$ & $\begin{array}{l}\text { There were } 74,284 \text { women with a term, } \\
\text { singleton birth during the study period } \\
\text { and with exposure data. Results suggest } \\
\text { that exposure during the first trimester } \\
\text { to relatively low levels of some air } \\
\text { pollutants may be associated with a } \\
\text { reduction in birth weight in term-born } \\
\text { infants. }\end{array}$ \\
\hline 2. & McKenzie, et al. & 2014 & Colorado, USA & $\begin{array}{l}\text { Cohort study; } \\
\text { Use of secondary data }\end{array}$ & $\begin{array}{l}\text { Information from publicly } \\
\text { accessible Colorado Oil and } \\
\text { Gas Information System } \\
\text { (COGIS). } \\
\text { Live birth data were also } \\
\text { obtained from the Colorado } \\
\text { Vital Birth Statistics. }\end{array}$ & $\begin{array}{l}\text { Results show an association between } \\
\text { density and proximity of natural gas } \\
\text { wells within a 10-mile radius of } \\
\text { maternal residence and prevalence of } \\
\text { Congenial Heart Defects (CHDs) and } \\
\text { possibly Neutral Tube Defects (NTDs). }\end{array}$ \\
\hline 3. & Magee, et al. & 2017 & Sydney & Conceptual paper & & $\begin{array}{l}\text { Hypertensive disorders are the most } \\
\text { common medical complication of } \\
\text { pregnancy. }\end{array}$ \\
\hline 4 & Harville, et al. & $2017 \mathrm{a}$ & USA & Survey & $\begin{array}{l}\text { Sample }(\mathrm{n}=1650 \text { women } \\
18-45 \text { years of age })\end{array}$ & $\begin{array}{l}\text { There is a link between exposure to oil } \\
\text { spill and hypertension. }\end{array}$ \\
\hline 5 & Harville, et al. & $2017 \mathrm{~b}$ & & Survey & $\begin{array}{l}\text { Sample }(\mathrm{n}=1524 \text { women } \\
\text { aged } 18-45)\end{array}$ & $\begin{array}{l}\text { An increased risk of miscarriage was } \\
\text { found with any exposure to the oil spill. }\end{array}$ \\
\hline 6. & $\begin{array}{c}\text { American Diabetes } \\
\text { Association }\end{array}$ & 2014 & & Position Paper & & \\
\hline 7. & NIHCM & 2010 & & Conceptual Paper & & \\
\hline 8. & $\begin{array}{l}\text { Bruederle } \\
\text { and Hodler }\end{array}$ & 2017 & Nigeria & $\begin{array}{c}\text { Survey, } \\
\text { Secondary data }\end{array}$ & $\begin{array}{l}\text { Sample }(\mathrm{n}=5043 \text { Infants; } \\
2744 \text { mothers) }\end{array}$ & $\begin{array}{l}\text { Oil spill has negative effects on } \\
\text { neonates and infants. }\end{array}$ \\
\hline 9. & $\begin{array}{c}\text { Adewale } \\
\text { and Mustapha }\end{array}$ & 2015 & Nigeria & Survey & Sample $(\mathrm{n}=100)$ & $\begin{array}{l}\text { Gas flaring causes health problems for } \\
\text { the people. }\end{array}$ \\
\hline 10 & Adelana et al. & 2011 & Nigeria & Conceptual paper & & \\
\hline 11. & Ejiba, et al. & 2016 & Nigeria & Conceptual paper & & \\
\hline 12. & $\mathrm{Li}$ and Carlson & 2014 & USA & Experimental & $\begin{array}{l}\text { Water samples of two } \\
\text { ground water wells in oil } \\
\text { producing areas }\end{array}$ & $\begin{array}{l}\text { Thermogenic methane was detected in } \\
\text { wells-indicating a potential } \\
\text { contamination. }\end{array}$ \\
\hline 13 & Osborn et al. & 2011 & USA & Experimental & $\begin{array}{l}\text { Water samples from } 60 \\
\text { drinking-water wells in oil } \\
\text { producing regions }\end{array}$ & $\begin{array}{l}51 \text { of } 60 \text { drinking water wells were } \\
\text { contaminated. }\end{array}$ \\
\hline 14. & Yakubu & 2017 & Nigeria & Evaluation study & Secondary data & $\begin{array}{l}\text { Oil spills and gas flaring lead to severe } \\
\text { health problems. }\end{array}$ \\
\hline 15. & Udok and Akpan & 2017 & Nigeria & Conceptual paper & & \\
\hline 16 & $\begin{array}{l}\text { United Nations } \\
\text { Environment } \\
\text { Program }\end{array}$ & 2011 & & Evaluation report & & \\
\hline 17 & Kadafa & 2012 & Nigeria & Descriptive study & Secondary data & $\begin{array}{l}\text { Oil pollution has caused the massive } \\
\text { contamination to sources of drinking } \\
\text { water, fishing grounds and so on. }\end{array}$ \\
\hline
\end{tabular}




\section{Continued}

\begin{tabular}{|c|c|c|c|c|c|c|}
\hline 18 & Sebastine, et al. & 2002 & Ecuador & Cross-sectional study & $\begin{array}{l}\text { Sample ( } \mathrm{n}=1250 \text { Women } \\
\text { aged } 17-45 \text { living in } 9 \\
\text { exposed communities and } \\
14 \text { unexposed communities) }\end{array}$ & $\begin{array}{l}\text { No association was found between } \\
\text { stillbirth and exposure to oil spill. }\end{array}$ \\
\hline 19 & Atubi & 2015 & Nigeria & Cross sectional study & $\begin{array}{l}\text { Sample ( } \mathrm{n}=9 \text { selected oil } \\
\text { communities in Delta State) }\end{array}$ & $\begin{array}{l}\text { Oil spillage and gas flaring have grave } \\
\text { effects on human health. }\end{array}$ \\
\hline 20 & $\begin{array}{l}\text { Murdoch Children's } \\
\text { Research Institute }\end{array}$ & 2014 & Australia & longitudinal & $\begin{array}{l}\text { Sample }(n=1500+\text { first } \\
\text { time mothers })\end{array}$ & $\begin{array}{l}\text { Maternal depression linked to social } \\
\text { factors. }\end{array}$ \\
\hline 21 & Rung, et al. & 2016 & USA & Survey & Sample ( $\mathrm{n}=2842$ women) & $\begin{array}{l}\text { Physical exposure to oil spills was found } \\
\text { to be significantly associated with } \\
\text { depressive symptoms. } \\
\text { Maternal depression linked to social } \\
\text { factors as well. }\end{array}$ \\
\hline 22 & Bell, et al. & 2010 & USA & $\begin{array}{l}\text { Descriptive/ } \\
\text { experimental Study }\end{array}$ & $\begin{array}{l}\text { PM2.5 Teflon filters } \\
\text { collected from } 4 \text { counties } \\
\text { were analysed for more } \\
\text { than } 50 \text { elements. } \\
\text { Data from National Centre } \\
\text { for Health Statistics on } \\
\text { 121,589 births matching } \\
\text { study's measurement data. }\end{array}$ & $\begin{array}{l}\text { Exposures of pregnant women to higher } \\
\text { levels of certain PM } 2.5 \text { chemical } \\
\text { constituents originating from specific } \\
\text { sources, such as the oil-combustion } \\
\text { associated elements vanadium and } \\
\text { nickel are associated with lower birth } \\
\text { weight. }\end{array}$ \\
\hline 23 & Chen, et al. & 2010 & China & Cross-sectional study & $\begin{array}{l}\text { Sample }(\mathrm{n}=81 \text { pairs of } \\
\text { mothers and newborns) }\end{array}$ & $\begin{array}{l}\text { Serum concentrations of several } \\
\text { measured PAHs were associated with a } \\
\text { decreased birth weight, although not } \\
\text { statistically significant. }\end{array}$ \\
\hline
\end{tabular}

\subsection{Oil Spill, Gas Flaring and Adverse Pregnancy Outcomes}

The available literature on oil pollution and pregnancy outcomes are scanty. Of the total reviewed articles, 13 focused on adverse pregnancy outcomes. These adverse pregnancy outcomes include miscarriages (spontaneous abortion) and stillbirths, low birth weight, birth defects, neonatal mortality, hypertensive disorders of pregnancy, gestational diabetes mellitus, and maternal depression. In the following sections, the various adverse pregnancy outcomes resulting from exposure to oil spill and gas flaring were reviewed in detail.

\subsubsection{Miscarriage/Spontaneous Abortion and Stillbirth}

Miscarriage and stillbirth are common disorders occurring in $15 \%-20 \%$ of human pregnancies [13]. Sebastián, Armstrong and Stephens [14], in a case-control study of 648 (365 from exposed communities and 283 from non-exposed communities) women living in the proximity of oil fields in the Amazon Basin of Ecuador, reported that 555 women (85.6\%) had at least one pregnancy within the study period. Of the women reporting at least one pregnancy, 508 (78.3\%) have had at least one liveborn child and 111 (17.1\%) had experienced a miscarriage (spontaneous abortion). Moreover, pregnancies of women living in exposed communities were more likely to end in spontaneous abortion when compared with pregnancies of women living in non-exposed communities. Ac- 
cording to the scholars, no association was found between stillbirth and exposure [14]. In a GROWH (Gulf Resilience on Women's Health) study by Harville et al. [15], using a sample of 1524 women aged 18 - 45, it was reported that an increased risk of miscarriage was found with any exposure to the oil spill, however they reiterated that the evidence was not strong enough to significantly associate miscarriage with exposure to oil spill.

\subsubsection{Low Birthweight}

Birthweight is a common indicator of fetal health; exposure to fine particles $\left(\mathrm{PM}_{2.5}\right)$ during pregnancy has been linked to lower birthweight [16]. In an experimental-descriptive study conducted by Bell et al. in USA using $\mathrm{PM}_{2.5}$ Teflon filters collected from four (4) counties and secondary data on 121,589 births matching the study's measurement data, it was reported that exposure of pregnant women to higher levels of certain $\mathrm{PM}_{2.5}$ chemical constituents originating from specific sources, such as the oil-combustion associated elements-vanadium and nickel, were associated with lower birthweight [16]. In a retrospective cohort study on 74,284 women with a term, singleton birth for whom adequate air monitoring data existed in at least one trimester, Dugandzic et al. investigated the relationship between low birthweight and ambient levels of particulate matter; and the results suggested that exposure during the first trimester to relatively low levels of some air pollutants may be associated with a reduction in birthweight in term-born infants [6].

A cross-sectional study on prenatal exposure to polycyclic aromatic hydrocarbons (PAHs) and birthweight in China by Chen et al. on 81 pairs of mothers and newborns from four hospitals, the scholars found that most of the measured PAHs in maternal serum and three PAHs in cord blood were inversely but not significantly associated with birthweight [17]. Moreover, the strongest associations were observed for higher concentrations of benzo (a) pyrene $(\mathrm{BaP})$ in maternal serum and anthracene (ANT) in cord blood. Furthermore, ANT and fluoranthene (FLT) were the predominant PAHs in the maternal and cord blood serum. The researchers noted that serum concentrations of several measured PAHs were associated with a decreased birthweight, although the findings were not found to be statistically significant.

\subsubsection{Birth Defects}

Based on current knowledge, the etiology of about $40 \%$ of birth defects has been recognized to date. Among various birth defects of known etiology, around 36\% are caused exclusively by genetic factors, whereas $50 \%-75 \%$ results from complex gene-environmental interactions [18]. According to Atubi, oil operations involve the release of hydrocarbons and other noxious materials into the atmosphere [19]. He further stated that gas combustion, with the generation of intense heat and flares coupled with the disposal of industrial wastes, may affect the fertility of the inhabitants in such a manner that fecundity may fall and the birth of abnormal babies may increase. 
Studies have found that oral clefts, neural tube defects (NTDs), and congenital heart defects (CHD) are the most common classes of birth defects. These defects are thought to originate in the first trimester as a result of polygenic inherited disease or gene-environment interactions. Suspected non-genetic risk factors for these birth defects include folate deficiency and maternal exposure to benzene, particulate matter $(\mathrm{PM})$, nitrogen dioxide $\left(\mathrm{NO}_{2}\right)$, polycyclic aromatic hydrocarbons (PAHs), petroleum-based solvents amongst others [20] [21] [22]. In a household survey of four (4) states across Iraq interviewing 6032 households' heads and data on more than 10,000 children and young people, Alborz's study found that there is an association between the reported presence of potential sources of contamination in local environments with higher numbers of resident children having birth defects [23]. Available literature seems to suggest that crude oil pollution tend to lead to higher incidences of adverse neonatal and maternal health effects. More empirical studies are needed to unravel these and proffer possible solutions.

\subsubsection{Neonatal Mortality}

Only one study was found on neonatal mortality in relation to the effects of oil spills that fit the selection criteria. Bruederle and Hodler [24], using spatial data from the Nigerian Oil Spill Monitor and the Demographic and Health Surveys as well as relying on the comparison of siblings conceived before and after nearby oil spills, investigated the effects of oil spills that occurred before conception or during pregnancy. They found that nearby oil spills double the neonatal mortality rate. These findings emanated from a combination of data about oil spills from the Nigerian Oil Spill Monitor and geo-referenced household survey data from the Nigeria Demographic and Health (DHS) Survey 2013 as well as unit's observatory study of infants born to mothers interviewed for the Nigeria DHS 2013. Their main sample incorporated all infants born from January 2006 and above, to mothers living in a cluster with a reported location less than $10 \mathrm{~km}$ away from any oil spill in their DHS records. In all, their sample consisted of 5043 infants born to 2744 different mothers living in 130 different clusters.

\subsubsection{Hypertensive Disorders of Pregnancy}

Self-reported exposure to the Gulf oil spill and hypertensive disorder in a 2017 second GROWH study conducted by Harville et al., on 1091 southern Louisiana women between the ages of 18 - 45, showed that $21 \%$ of the 631 women who had a pregnancy both before and after the oil spill reported having hypertension as a result of exposure to the oil spill [11]. This finding, however was not found to be significant. Furthermore, 386 women's medical records abstracted in this study revealed that hypertensive disorders were more common only in those reporting contact with oil (aOR 3.13, 95\% Cl: 1.05 - 9.35).

\subsubsection{Gestational Diabetes Mellitus (GDM)}

In the same second GROWH study by Harville et al., pregnant women who reported oil spill exposure had increased risk of gestational diabetes mellitus [11]. 
The sensitivity analysis conducted on 695 women whose pregnancies occurred within two years of the oil spill revealed that about $9 \%$ of the pregnant women reported having GDM.

\subsubsection{Maternal Depression}

Based on a sample population of 2842 women in southern coastal Louisiana between 2012 and 2014, over $28 \%$ of the sample population reported symptoms of depression, $13 \%$ reported severe mental distress, $16 \%$ reported an increase in the number of fights with their partners, and $11 \%$ reported an increase in the intensity of partner fights. Physical exposure to oil spills was found to be significantly associated with depressive symptoms and domestic conflict. The study reported high rates of poor mental health outcomes among women in southern coastal Louisiana, an oil spill disaster-prone area [13]. Similarly, maternal depression has been found to lead to serious health risks for both the mother and infant. It has been found to increase the risk for adverse complications during birth and causing long-lasting or even permanent effects on child development and well-being [12] [25].

\subsection{Potential Exposure Pathways}

A total of 10 studies were identified and reviewed for potential pathways of pollutants as it relates to oil pollution.

Human exposure to pollutants from oil spills and gas flaring occurs through oral routes like eating and drinking, through the skin when cleaning and bathing, via inhalation of airborne contaminants as well as through contaminated land/soil [26]. Oil pollution can contaminate both surface and groundwater. When the oil is spilt, it spreads on the surfaces of water and also leaches into groundwater. It is known that health risk is not averted by abstinence from fish killed by spilt oil. Some of the fishes and animals that escape instant death from oil pollution are known to have taken in some of the toxic substances, which in turn get into human systems when eaten [1] [19] [27]. Besides, chemicals from gas flare and oil spill are transferred to the drinking water in close proximity to natural gas wells [28] [29]. In the same manner, oil and natural gas production processes contribute numerous contaminants into the air. Many of these pollutants are dangerous if inhaled in large amounts from the ambient air.

In a study examining environmental health problems in Ogoniland, Yakubu found that environmental pollutants discharged from gas flaring in communities of the Niger Delta, highly impacts the air quality in the host communities and this has detrimental effects on the people living in such communities [30]. As noted by Yakubu, the negative effects of gas flaring are enormous because gas flaring involves the atmospheric discharge of hazardous substances and these substances are environmentally unfriendly. The release of these substances into the air constitutes a major source of air pollution that has had very severe environmental and health consequences in the Niger Delta region [30]. Furthermore, Yakubu found that air pollutants due to gas flares are known to exhibit some 
level of correlation with developmental, neurological, and reproductive abnormalities [30].

Oil spills and flared gas end up in the environment including water, air and soil contaminating waterways and sources of water for domestic use; polluting the air as well as affecting the quality of the soil for farming. Once underground, the polluted water system is transported within and between water systems that end up in wells and streams that supply the surrounding communities. These communities depend on such water resources as their only source of drinking water [31]. To date, water pollution remains one of the major environmental public health problems arising from extensive oil operations in the Niger Delta region of Nigeria. Moreover, the health of a considerable number of residents living in communities hosting oil wells in the Niger Delta region has been severely affected due to surface and underground water contamination [32]. Air pollution is not left out, as gas flaring contaminates the air and is believed to be a major source of air pollution in the Niger Delta region [33], resulting in unquantifiable damage to human life.

One notable effect of gas flaring is acid rain. The primary causes of acid rain are emissions of Sulphur dioxide $\left(\mathrm{SO}_{2}\right)$ and Nitrogen oxides $\left(\mathrm{NO}_{\mathrm{x}}\right)$ which combine with atmospheric moisture to form sulfuric acid and nitric acid respectively. Besides, the flares associated with gas flaring give rise to atmospheric contaminants which include oxides of Nitrogen, Carbon and Sulphur $\left(\mathrm{NO}_{x}, \mathrm{CO}_{2}, \mathrm{CO}\right.$, $\mathrm{SO}_{2}$ ), particulate matter, hydrocarbons and ash, photochemical oxidants, and Hydrogen sulphide $\left(\mathrm{H}_{2} \mathrm{~S}\right)$. These contaminants acidify the soil, deplete soil nutrient and stunt the growth of crops. Moreover, these contaminants are associated with a variety of adverse health impacts including adverse pregnancy outcomes and deformities in children. This is because people depend enormously on their environment for sustenance and survival. Any incidence which affects these key resources, that is, air, water and soil, would surely affect their health [3] [27].

\section{Discussion}

Based on the review of existing literature, empirical evidence suggests that there is a wide range of risk factors associated with oil pollution that occurs within communities hosting crude oil wells and natural gas; and the effects of oil pollution on a vulnerable population such as pregnant women, cannot be overemphasized. Moreover, the review revealed that oil spill and gas flare pollutants pathways such as air, water, and soil, have been found to contribute adversely to health risks and negative pregnancy outcomes in affected communities. While reviewed studies linked adverse pregnancy outcomes to exposure to pollutants from oil spill and gas flaring, there is a paucity of research with regards to the effects of oil spill and gas flaring on pregnant women in communities hosting crude oil wells and natural gas in Nigeria. Moreover, to the best of our knowledge, there was no empirical study found on the exposure pathways for these 
vulnerable populations in the Niger Delta region of Nigeria. As crude oil extraction is a major economic activity in the Niger Delta region, it calls for more empirical research. There is need for urgent public health considerations as well as research-driven policy formulation to reduce, if not eliminate the effects of the oil spill and gas flaring on vulnerable populations such as pregnant women in the Niger Delta region in Nigeria.

The reviewed articles showed a variety of methods employed by researchers ranging from the use of cohort studies to the use of publicly available data. The review showed that most of the studies employed a comparative method between exposed pregnant women and unexposed pregnant women groups to oil pollutants which do not allow for an all-around detailed assessment of subjective trends which cannot be captured through high-end quantitative studies. There are associated studies on exposure to oil pollution and miscarriages and stillbirths; hypertensive disorders; maternal depression and birth defects amongst other possible adverse pregnancy outcomes. However, only one study was found incorporating the observation method, alongside secondary data, to examine this relationship. Sometimes, exposure to pollutants due to oil spill and gas flare could be deliberate and could be embedded in the cultural, social and religious practices of the people. These are subjective factors which can only be investigated adequately through qualitative methods. However, to the best of our knowledge, no study was found investigating this interface.

Despite varied methodological approaches and diverse focus of enquiries, there was no pattern found for exposure pathways to pollutants for pregnant women residing in the oil-polluted area. Only a general trend, capturing a whole population, was inferred - like eating unwholesome food, drinking contaminated water and inhaling polluted air within the polluted environment.

\section{Conclusion}

This work focused on peer-reviewed literature addressing various adverse pregnancy outcomes as a result of exposure to oil pollutants in the environment. The review suggests that pregnant women in close proximity to oil polluted areas may be at higher risk of experiencing hypertensive disorders of pregnancy, gestational diabetes mellitus, maternal depression, miscarriages amongst others and three major pathways of exposure were identified as through air, water and soil. Studies reviewed employed different types of methodologies and cut across different fields of study. Future studies will need to improve on what past researchers have done. New research studies should use robust methodologies and also studies that focus on the effects of oil pollution exposure and its pathways on pregnant women in oil hosting regions. This review may be beneficial to drive policy and improve the health status of pregnant women in oil-polluted areas.

\section{Acknowledgements}

This study was supported by the Pan African University (PAU), of the African 
Union Commission (AU) as part of my Ph.D. in Reproductive Health Sciences.

\section{Conflicts of Interest}

The authors declare no conflicts of interest regarding the publication of this paper.

\section{References}

[1] Adelana, S.O., Adeosun, T.A., Adesina, A.O. and Ojuroye, M.O. (2011) Environmental Pollution and Remediation: Challenges and Management of Oil Spillage in the Nigerian Coastal Areas. American Journal of Scientific and Industrial Research, 2, 834-845. https://doi.org/10.5251/ajsir.2011.2.6.834.845

[2] Amnesty International (2009) Nigeria: Petroleum, Pollution and Poverty in the Niger Delta. https://www.amnesty.org

[3] Kadafa, A.A. (2012) Oil Exploration and Spillage in the Niger Delta of Nigeria. Civil and Environmental Research, 2, 38-51.

[4] Johnson, J.E., Lim, E. and Roh, H. (2019) Impact of Upstream Oil Extraction and Environmental Public Health: A Review of the Evidence. Science of the Total Environment, 657, 187-199. https://doi.org/10.1016/j.scitotenv.2018.11.483

[5] Oladipupo, S.O., Mudashiru, R.B., Oyeleke, M.O. and Bakare, S.B. (2016) Review of some Impacts of Oil Exploration and Production in Niger Delta, Nigeria. International Conference of Science, Engineering and Environmental Technology, 1, 90-103.

[6] Dugandzic, R., Dodds, L., Stieb, D. and Smith-Doiron, M. (2006) The Association between Low-Level Exposures to Ambient Air Pollution and Term Low Birth Weight: A Retrospective Cohort Study. Environmental Health: A Global Access Science Source, 5, 3. https://doi.org/10.1186/1476-069X-5-3

[7] Sram, R.J., Binkova, B., Dejmek, J. and Bobak, M. (2005) Ambient Air Pollution and Pregnancy Outcomes: A Review of the Literature. Environmental Health Perspectives, 113, 375-382. https://doi.org/10.1289/ehp.6362

[8] Grason, H.A. and Misra, D.P. (2009) Reducing Exposure to Environmental Toxicants before Birth: Moving from Risk Perception to Risk Reduction. Public Health Reports, 124, 629-641. https://doi.org/10.1177/003335490912400505

[9] Sly, P.D., Carpenter, D.O., Van den Berg, M., Stein, R.T., Larderyan, P.J., Brune-Drisse, M. and Suk, W. (2016) Health Consequences of Environmental Exposures: Causal Thinking in Global Environmental Epidemiology. Annals of Global Health, 82, 3-9. https://doi.org/10.1016/j.aogh.2016.01.004

[10] Balise, V.D., Meng, C., Cornelius-Green, J.N., Kassotis, C.D., Kennedy, R. and Nagel, S.C. (2016) Systematic Review of the Association between Oil and Natural Gas Extraction Processes and Human Reproduction. Fertility and Sterility, 106, 795-819. https://doi.org/10.1016/j.fertnstert.2016.07.1099

[11] Harville, E.W., Shankar, A., Zilversmit, L. and Buekens, P. (2017) Self-Reported Oil Spill Exposure and Pregnancy Complications: The GROWH Study. International Journal of Environmental Research and Public Health, 14, 692. https://doi.org/10.3390/ijerph14070692

[12] Rung, A.L., Gaston, S., Oral, E., Robinson, W.T., Fontham, E., Harrington, D.J., Trapido, E. and Peters, E.S. (2016) Depression, Mental Distress, and Domestic Conflict among Louisiana Women Exposed to the Deepwater Horizon Oil Spill in the WaTCH Study. Environmental Health Perspectives, 124, 1429-1435. 
https://doi.org/10.1289/EHP167

[13] Webb, E., Bushkin-Bedient, S., Cheng, A., Kassotis, C.D., Balise, V. and Nagel, S.C. (2014) Developmental and Reproductive Effects of Chemicals Associated with Unconventional Oil and Natural Gas Operations. Reviews on Environmental Health, 29, 307-318. https://doi.org/10.1515/reveh-2014-0057

[14] Sebastián, M.S., Armstrong, B. and Stephens, C. (2002) Outcomes of Pregnancy among Women Living in the Proximity of Oil Fields in the Amazon Basin of Ecuador. International Journal of Occupational and Environmental Health, 8, 312-319. https://doi.org/10.1179/oeh.2002.8.4.312

[15] Harville, E.W., Shankar, A., Zilversmit, L. and Buekens, P. (2018) The Gulf Oil Spill, Miscarriage, and Infertility: The GROWH Study. International Archives of Occupational and Environmental Health, 91, 47-58. https://doi.org/10.1007/s00420-017-1257-4

[16] Bell, M.L., Belanger, K., Ebisu, K., Gent, J.F., Lee, H.J., Koutrakis, P. and Leaderer, P.B. (2010) Prenatal Exposure to Fine Particulate Matter and Birth Weight. Epidemiology, 21, 884-891. https://doi.org/10.1097/EDE.0b013e3181f2f405

[17] Chen, Q., Zheng, T., Bassig, B.A., Cheng, Y., Leaderer, B., Lin, S., Holford, T., Qiu, J., Zhang, Y., Shi, K., Zhu, Y., Niu, J., Li, Y., Guo, H., Hu, X. and Jin, Y. (2014) Prenatal Exposure to Polycyclic Aromatic Hydrocarbons and Birth Weight in China. Open Journal of Air Pollution, 3, 100-110. https://doi.org/10.4236/ojap.2014.34010

[18] Al-Hadithi, T., Al-Diwan, J.K., Saleh, A.M. and Shabila, N.P. (2012) Birth Defects in Iraq and the Plausibility of Environmental Exposure: A Review. Conflict and Health, 6, 3. https://doi.org/10.1186/1752-1505-6-3

[19] Atubi, A. O. (2015) Effects of Oil Spillage on Human Health in Producing Communities of Delta State, Nigeria. European Journal of Business and Social Sciences, 4, 14-30.

[20] Colborn, T., Kwiatkowski, C., Schultz, K. and Bachram, M. (2011) Natural Gas Operations from a Public Health Perspective. Human and Ecological Risk Management, 17, 1039-1056. https://doi.org/10.1080/10807039.2011.605662

[21] Khader, Y., Abdelrahman, M., Abdo, N., Awad. S., Al-Sharif, M., Elbetieha, A. and Malkawi, M. (2016) Exposure to Air Pollution and Pregnancy Outcomes in the East Mediterranean Region: A Systematic Review. International Journal of Paediatrics, 4 , $1255-1271$.

[22] McKenzie, L.M., Guo, R., Witter, R.Z., Savitz, D.A., Newman, L.S. and Adgate, J.L. (2014) Birth Outcomes and Maternal Residential Proximity to Natural Gas Development in Rural Colorado. Environmental Health Perspectives, 122, 4.

https://doi.org/10.1289/ehp.1306722

[23] Alborz, A. (2013) Environmental Characteristics and Prevalence of Birth Defects among Children in Post-War Iraq: Implications for Policies on Rebuilding the Iraqi Education System. Medicine, Conflict and Survival, 29, 26-44. https://doi.org/10.1080/13623699.2013.765197

[24] Bruederle, A. and Hodler, R. (2017) The Effect of Oil Spills on Infant Mortality: Evidence from Nigeria. CESifo Working Papers No. 6653.

[25] Murdoch Children's Research Institute. (2014) Maternal Depression. Translating Evidence from the Maternal Health Study to inform Policy and Practice. Policy Brief 1. https://www.mcri.edu.au/documents

[26] Adewale, O.O. and Mustapha, U. (2015) The Impact of Gas Flaring in Nigeria. International Journal of Science, Technology and Society, 3, 40-50. 
https://doi.org/10.11648/j.ijsts.20150302.12

[27] Ejiba, I.V., Onya, S.C. and Adams, O.K. (2016) Impact of Oil Pollution on Livelihood: Evidence from the Niger Delta Region of Nigeria. Journal of Scientific Research and Reports, 12, 1-12. https://doi.org/10.9734/JSRR/2016/26633

[28] Li, H. and Carlson, K.H. (2014) Distribution and Origin of Groundwater Methane in the Wattenberg Oil and Gas Field of Northern Colorado. Environmental Science and Technology, 48, 1484-1491. https://doi.org/10.1021/es404668b

[29] Osborn, S.G., Vengosh A., Warner, N.R. and Jackson, R.B. (2011) Methane Contamination of Drinking Water Accompanying Gas-Well Drilling and Hydraulic Fracturing. Proceedings of the National Academy of Sciences of the United States of America, 108, E665-E666. https://doi.org/10.1073/pnas.1109270108

[30] Yakubu, O.H. (2017) Addressing Environmental Health Problems in Ogoniland through Implementation of United Nations Environment Program Recommendations: Environmental Management Strategies. Environments, 4, 28. https://doi.org/10.3390/environments4020028

[31] Frynas, J.G. (2000) Oil in Nigeria: Conflict and Litigation between Oil Companies and Village Communities. LIT Verlag, Hamburg, Germany.

[32] United Nations Environment Programme (2011) Environmental Assessment of Ogoniland. United Nations Environment Programme, Nairobi, Kenya.

[33] Udok, U. and Akpan, E.B. (2017) Gas Flaring in Nigeria: Problems and Prospects. Global Journal of Politics and Law Research, 5, 16-28. 